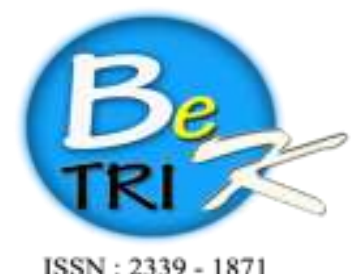

ISSN : $2339-1871$
JURNAL ILMIAHBETRIK

Besemah Teknologi Informasi dan Komputer

Editor Office : LPPM Sekolah Tinggi Teknologi Pagar Alam, Jn. Masik Siagim No. 75

Simpang Mbacang, Pagar Alam, SUM-SEL, Indonesia

Phone : $+62852-7901-1390$.

Email : betrik@sttpagaralam.ac.id | admin.jurnal@sttpagaralam.ac.id

Website: htips:/lejoumal.stipagaralam ac id/index php/betrik/index

\title{
SISTEM INFORMASI DAN VERIFIKASI PENGOLAHAN DATA GURU SERTIFIKASI PADA DINAS PENDIDIKAN KABUPATEN MUSIRAWAS
}

\author{
Lukman Sunardi ${ }^{1}$, Andri Anto Tri Susilo ${ }^{2}$ \\ Program Studi Informatika Universitas Bina Insan \\ Jalan Masik Siagim No.75 Simpang Mbacang Kec.Dempo Tengah Kota Pagar Alam \\ Sur-el :lukmanmmci@gmail.com ${ }^{1}$, andrellg@gmail.com²
}

\begin{abstract}
Abstrak: Salah satu bagian penting dalam pelaksanaan sertifikasi guru adalah proses rekrutmen dan penetapan calon pesertanya yang selanjutnya akan dilakukan pengolahan database yang berkaitan dengan sistem informasi, terutama dalam hal pendataan pelaporan tugas sertifikasi guru. Saat ini guru sulit mendapatkan informasi dan memantau status kelengkapan serta pelaporan data sertifikasi yang meraka ajukan, untuk guru yang tinggal di wilayah dekat dengan perkantoran Dinas pendidikan bukanlah suatu masalah tapi bagi guru yang tinggal jauh dari perkantoran ini merupakan masalah karena jarak tempuh ke kantor Dinas Pendidikan yang jauh. Tunjangan Profesi guru akan keluar jika data guru yang di entrykan di aplikasi dapodikdas tidak valid maka tunjangan di tunda sampai semua data valid. Guna mendukung perubahan dalam proses pelaksanaan sertifikasi guru maka sangat diperlukan sebuah sistem yang dibangun menggunakan PHP dan Mysql untuk memantau dan pelaporan berkas secara online guna mempercepat proses pencairan gaji sertifikasi guru pada Dinas Pendidikan Kabupaten Musirawas. Sistem yang berjalan secara online memudahkan tim sertifikasi dalam pengumpulan berkas karena data secara langsung masuk kedalam basis data. Dengan adanya sistem informasi verifikasi data guru sertifikasi proses pelaporan dan pembayaran sertifikasi tidak terhambat oleh data yang tidak lengkap.
\end{abstract}

Kunci Utama: Sertifikasi, Sistem, Guru.

Abstract: An important part of the implementation of teacher certification is the process of recruitment and determination of prospective participants, which will then be processed by a database relating to information systems, especially in terms of data collection on the reporting of teacher certification tasks. At present teachers find it difficult to obtain information and monitor the status of completeness and reporting of certification data which they propose, for teachers who live in areas close to the Office of Education office is not a problem but for teachers who live far from offices this is a problem because the distance to the Office of Education Office far away. Teacher 
professional allowance will come out if the teacher data entered in the Dapodikdas application is invalid then the allowance is postponed until all data is valid. To support changes in the process of implementing teacher certification, a system for monitoring and reporting files online is very necessary to accelerate the process of disbursing teacher certification salaries at the District Education Office in Musirawas. The system that runs online makes it easy for the certification team to collect files because the data is directly entered into the database. With the existence of the teacher certification data verification information system the reporting process and certification payment is not hampered by incomplete data.

Keywords : Certification, System, Teacher

\section{PENDAHULUAN}

Pelaksanaan Sertifikasi Guru merupakan salah satu wujud implementasi dari Undang-Undang Nomor 14 Tahun 2005 tentang Guru dan Dosen. Tahun 2017 merupakan tahun kesebelas pelaksanaan sertifikasi guru yang telah dilaksanakan sejak tahun 2007.Perbaikan penyelenggaraan sertifikasi guru terus dilakukan dari tahun ke tahun untuk mendapatkan hasil yang lebih baik.

Salah satu bagian penting dalam pelaksanaan sertifikasi guru adalah proses rekrutmen dan penetapan calon pesertanya yang selanjutnya akan dilakukan pengolahan database yang berkaitan dengan sistem informasi, terutama dalam hal pendataan pelaporan tugas sertifikasi guru.

Saat ini guru sulit mendapatkan informasi dan memantau status kelengkapan serta pelaporan data sertifikasi yang meraka ajukan, untuk guru yang tinggal di wilayah dekat dengan perkantoran Dinas pendidikan bukanlah suatu masalah tapi bagi guru yang tinggal jauh dari perkantoran ini merupakan masalah karena jarak tempuh ke kantor Dinas Pendidikan yang jauh.

Tunjangan Profesi guru pada tahun 2017 tidak jauh berubah dalam persyaratannya. SK Dirjen akan keluar jika data guru yang di entrykan di aplikasi dapodikdas valid maka tunjangan di tunda sampai semua data valid.

Namun sering terjadi kesalahan dalam entry akan berdampak terhadap SK Dirjen yang merupakan dasar pembayaran tunjangan profesi guru, maka dalam pengisian dapodikdas harus mengecek info ptknya apakah jam sudah linier dan cukup 24 jam per minggu semua data yang ada di dinas pendidikan harus valid dengan dapodik dan simtun jika tidak valid maka tunjangan ditunda.

Tim sertifikasi Dinas Pendidikan kesulitan dalam pengumpulan berkas sehingga memperlambat proses pencairan dana sertifikasi guru dan pembuatan laporan.

Guna mendukung perubahan dalam proses pelaksanaan sertifikasi guru maka sangat diperlukan sebuah sistem untuk 
memantau dan pelaporan berkas secara online guna mempercepat proses pencairan gaji sertifikasi guru pada Dinas Pendidikan Kabupaten Musirawas. Sistem yang berjalan secara online memudahkan tim sertifikasi dalam pengumpulan berkas karena data secara langsung masuk kedalam basis data.

Berdasarkan penjabaran permasalahan diatas maka penulis ingin menyelesaikan permasalahan tersebut melalui penulisan penelitian ini dengan judul "Perancangan Sistem Informasi dan Verifikasi Pengolahan Data Guru Sertifikasi Pada Dinas Pendidikan Kabupaten Musirawas", diharapkan dengan adanya sistem ini maka dapat mempercepat proses pencairan dana sertifikasi yang bersih dan adil.

\section{METODE PENELITIAN}

Pada penelitian ini penulis menggunakan metode deskriptif sebagai prosedur pemecahan masalah yang diselidiki dengan menggambarkan keadaan subjek atau objek dalam penelitian dapat berupa orang, lembaga, masyarakat dan yang lainnya yang pada saat sekarang berdasarkan fakta-fakta yang tampak atau apa adanya.

\subsection{Sistem}

Perancangan suatu aplikasi dilakukan adalah memodelkan kebutuhan pemakai. Ada banyak cara untuk memodelkan aplikasi sebagaimana banyak cara yang digunakan oleh seorang arsitek untuk membangun sebuah rumah. Pada dasarnya pemodelan tersebut merupakan kombinasi antara perangkat lunak dan perangkat keras yang digunakan (Whitten et $a l, 2005)$.

Perancangan suatu aplikasi termasuk dalam kegiatan rekayasa perangkat lunak. Proses rekayasa perangkat lunak dimulai jauh sebelum coding dilakukan dan berlanjut sampai tercapainya sebuah aplikasi yang diinginkan (Pohan, 1997). Pada dasarnya Rekayasa Perangkat Lunak dilakukan untuk merancang suatu aplikasi atau software dengan mengurutkan transformasi masalah menjadi solusi perangkat lunak yang dapat bekerja dengan baik

\subsection{Informasi}

Pengertian Informasi Menurut Tata Sutabri (2005) adalah data yang telah diklasifikasikan atau diolah atau diinterprestasikan untuk digunakan dalam proses pengambilan keputusan.

Kualitas informasi ditentukan oleh beberapa faktor yaitu sebagai berikut :

1. Keakuratan dan teruji kebenarannya. Informasi harus bebas dari kesalahan-kesalahan dan tidak menyesatkan.

\section{Kesempurnaan informasi}


Informasi disajikan dengan lengkap tanpa pengurangan, penambahan, dan pengubahan.

3. Tepat waktu

Infomasi harus disajikan secara tepat waktu, karena menjadi dasar dalam pengambilan keputusan.

4. Relevansi

Informasi akan memiliki nilai manfaat yang tinggi, jika Informasi tersebut dapat diterima oleh mereka yang membutuhkan.

5. Mudah dan murah

Apabila cara dan biaya untuk memperoleh informasi sulit dan mahal, maka orang menjadi tidak berminat untuk memperolehnya, atau akan mencari alternatif substitusinya (Budi Sutedjo Dharma Oetomo, 2002 : 16 -17).

Kualitas suatu informasi tergantung dari tiga hal, yaitu :

1. Akurat, berarti informasi harus bebas dari kesalahan-kesalahan dan harus jelas mencerminkan maksudnya.

2. Tepat pada waktunya, berarti informasi yang diterima tidak boleh terlambat.

3. Relevan, berarti informasi tersebut mempunyai manfaat dari pemakainya.

\subsection{Verifikasi}

Pengertian verifikasi data adalah pembentukan kebenaran suatu teori, atau fakta atas data yang dikumpulkan. Pada verifikasi data biasanya data yang dikumpulkan akan diolah dan kemudian dianalisis agar dapat diuji secara hipotesis. Hipotesis kemudian diuji menggunakan fakta empirik agar mendapatkan jawaban yang benar secara ilmiah

\subsection{Sertifikasi Guru}

Guru mempunyai kedudukan sebagai tenaga profesional pada jalur pendidikan formal yang diangkat sesuai dengan peraturan perundangundangan.

Pengakuan kedudukan guru sebagai tenaga professional dibuktikan dengan sertifikat pendidik. Lebih lanjut UndangUndang Nomor 14 Tahun 2005 tentang Guru dan Dosen mendefinisikan bahwa profesional adalah pekerjaan atau kegiatan yang dilakukan oleh seseorang dan menjadi sumber penghasilan kehidupan yang memerlukan keahlian, kemahiran, atau kecakapan yang memenuhi standar mutu atau norma tertentu serta memerlukan pendidikan profesi. 
Sebagai tenaga profesional, guru diharapkan dapat meningkatkan martabat dan perannya sebagai agen pembelajaran.Sertifikasi guru sebagai upaya peningkatan mutu guru diharapkan dapat meningkatkan mutu pembelajaran dan mutu pendidikan di Indonesia secara berkelanjutan. Pelaksanaan sertifikasi guru dimulai sejak tahun 2007 setelah diterbitkannya Peraturan Mendiknas Nomor 18 Tahun 2007 tentang Sertifikasi bagi Guru dalam Jabatan. Landasan hukum yang digunakan sebagai dasar penyelenggaraan sertifikasi guru sejak tahun 2009 adalah Peraturan Pemerintah Nomor 74 Tahun 2008 tentang Guru.Tahun 2013 merupakan tahun ketujuh pelaksanaan sertifikasi guru dalam jabatan

\subsection{Metode Pengembangan Sistem}

SDLC adalah tahapan-tahapan pekerjaan yang dilakukan oleh analis sistem dan programmer dalam membangun sistem informasi. Langkah yang digunakan meliputi:
1. Melakukan survei dan menilai kelayakan proyek pengembangan sistem informasi

2. Mempelajari dan menganalisis sistem informasi yang sedang berjalan

3. Menentukan permintaan pemakai sistem informasi

4. Memilih solusi atau pemecahan masalah yang paling baik

5. Menentukan perangkat keras (hardware) dan perangkat lunak (software)

6. Merancang sistem informasi baru

7. Membangun sistem informasi baru

8. Mengkomunikasikan dan mengimplementasikan sistem informasi baru

9. Memelihara dan melakukan perbaikan/peningkatan sistem informasi baru bila diperlukan 


\subsection{Diagram Kontek}

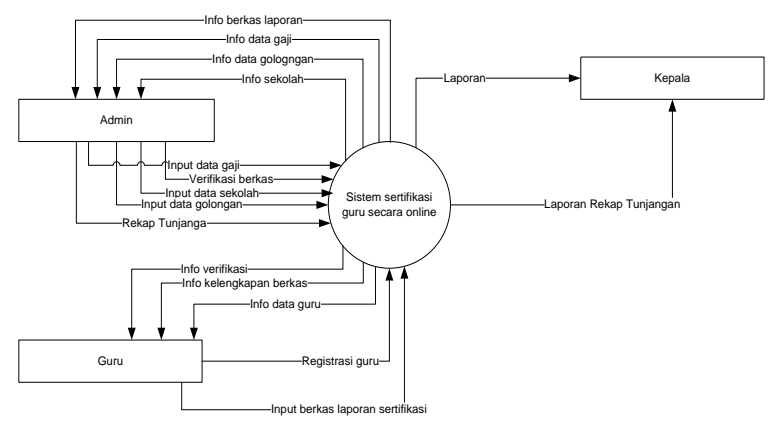

Gambar 1. Diagram Konteks

\subsection{Data Flow Diagram Level 0}

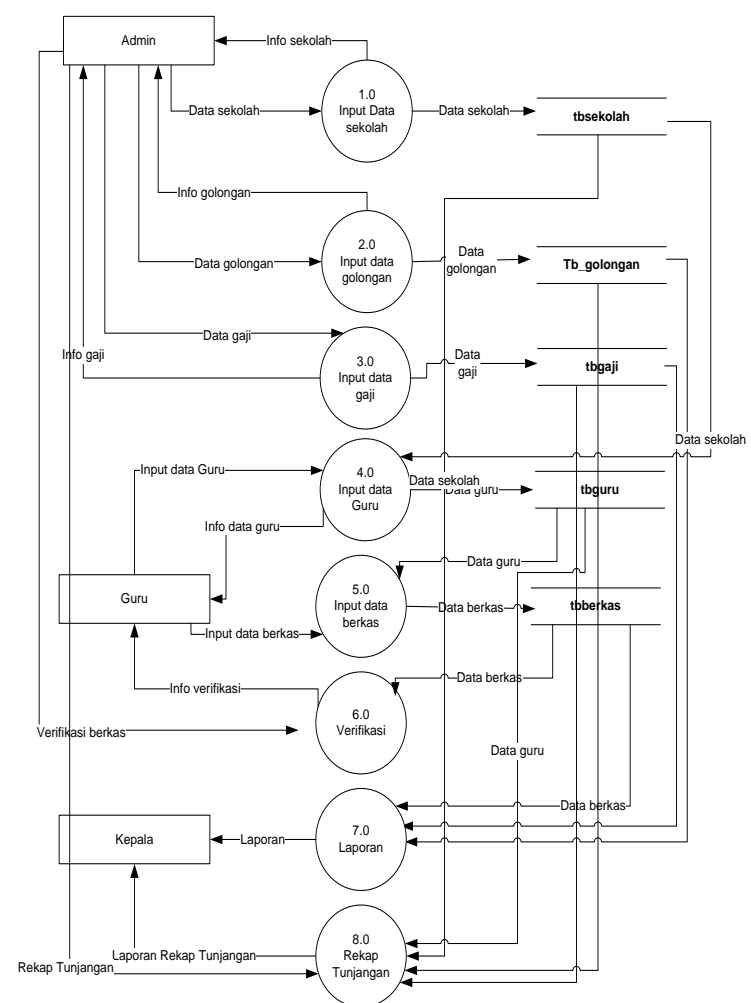

Gambar 2. DFD Level 0

\subsection{Entity Relationship Diagram}

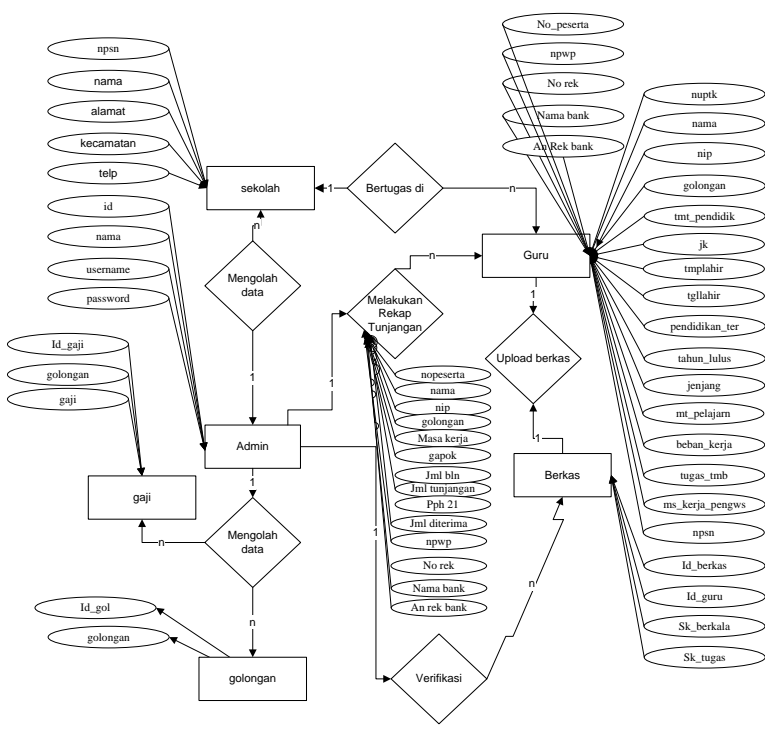

\section{Gambar 3. ERD}

\subsection{Desain Tabel}

Perancangan aplikasi ini menggunakan basis data My-SQL dimana penulis membuat sebuah database dengan nama db_sertifikasi. Database ini terdiri atas 9 tabel seperti berikut ini :

1) Tabel Login

Tabel login digunakan untuk menyimpan nama administrator sistem. Adapun rancangannya seperti pada tabel 1 berikut :

\section{Tabel 1 Tabel Login}

\begin{tabular}{|c|c|c|c|c|}
\hline \multicolumn{2}{|c|}{$\begin{array}{l}\text { Nama Tabel } \\
\text { Index }\end{array}$} & \multicolumn{3}{|c|}{$\begin{array}{l}\text { : tblogin } \\
\text { : iduser (PRIMARY KEY) }\end{array}$} \\
\hline No & $\begin{array}{l}\text { Nama } \\
\text { Field }\end{array}$ & $\begin{array}{l}\text { Type } \\
\text { Field }\end{array}$ & Panjang & Keterangan \\
\hline 1 & iduser & Int & 3 & Id user \\
\hline
\end{tabular}


Author 1, Author2

\begin{tabular}{|l|l|l|c|l|}
\hline 2 & username & Varchar & 30 & Nama user \\
\hline 3 & password & Varchar & 30 & $\begin{array}{l}\text { Password } \\
\text { pengguna }\end{array}$ \\
\hline
\end{tabular}

2) Tabel Sekolah

Tabel sekolah digunakan untuk menyimpan data-data sekolah di Kabupaten Musirawas. Adapun rancangannya seperti pada tabel 2 berikut :

\section{Tabel 2 Tabel Data Sekolah}

\begin{tabular}{|l|l|c|c|l|}
\hline \multicolumn{4}{|l|}{$\begin{array}{l}\text { Nama Tabel } \\
\text { Index }\end{array}$} & $\begin{array}{l}\text { : tbsekolah } \\
: \text { NPSN (PRIMARY KEY) }\end{array}$ \\
\hline $\begin{array}{c}\text { N } \\
\text { o }\end{array}$ & $\begin{array}{c}\text { Nama } \\
\text { Field }\end{array}$ & $\begin{array}{c}\text { Type } \\
\text { Field }\end{array}$ & $\begin{array}{c}\text { Panjan } \\
\text { g }\end{array}$ & $\begin{array}{c}\text { Keteranga } \\
\text { n }\end{array}$ \\
\hline 1 & npsn & Int & 12 & $\begin{array}{l}\text { Nomor } \\
\text { induk } \\
\text { sekolah }\end{array}$ \\
\hline 2 & nama & Varchar & 50 & $\begin{array}{l}\text { Nama } \\
\text { sekolah }\end{array}$ \\
\hline 3 & alamat & Varchar & 50 & $\begin{array}{l}\text { Alamat } \\
\text { sekolah }\end{array}$ \\
\hline 4 & $\begin{array}{l}\text { kecamata } \\
\text { n }\end{array}$ & Varchca \\
r & 35 & Kecamatan \\
\hline 5 & telepon & Varchar & 13 & No telp \\
\hline
\end{tabular}

\section{3) Tabel Guru}

Tabel guru digunakan untuk menyimpan data guru. Rancangannya dapat pada tabel 3 berikut :

\section{Tabel 3 Tabel Guru}

\begin{tabular}{|c|c|c|c|c|}
\hline \multicolumn{2}{|c|}{$\begin{array}{l}\text { Nama Tabel } \\
\text { Index }\end{array}$} & \multicolumn{3}{|c|}{$\begin{array}{l}\text { : tbguru } \\
\text { : nuptk (PRIMARY KEY) }\end{array}$} \\
\hline $\begin{array}{l}\mathbf{N} \\
\mathbf{0}\end{array}$ & Nama Field & $\begin{array}{l}\text { Type } \\
\text { Field }\end{array}$ & $\begin{array}{c}\text { Panja } \\
\text { ng }\end{array}$ & $\begin{array}{c}\text { Keteranga } \\
\text { n }\end{array}$ \\
\hline 1 & nuptk & Varch & 16 & Nomor \\
\hline
\end{tabular}


4) Tabel Gologan

Tabel gologan digunakan untuk menyimpan nama golongan guru. Adapun rancangannya seperti pada tabel 4 berikut :

\section{Tabel 4 Tabel gologan}

\begin{tabular}{|l|l|c|c|l|}
\hline \multicolumn{4}{|l|}{$\begin{array}{l}\text { Nama Tabel } \\
\text { Index }\end{array}$} & \multicolumn{3}{l|}{$\begin{array}{l}\text { : tb_golongan } \\
\text { : id_golongan (PRIMARY KEY) }\end{array}$} \\
\hline $\begin{array}{c}\text { N } \\
\text { o }\end{array}$ & $\begin{array}{c}\text { Nama } \\
\text { Field }\end{array}$ & $\begin{array}{c}\text { Type } \\
\text { Field }\end{array}$ & $\begin{array}{c}\text { Panja } \\
\text { ng }\end{array}$ & Keterangan \\
\hline 1 & $\begin{array}{l}\text { Id_golon } \\
\text { gan }\end{array}$ & Int & 5 & Id gologan \\
\hline 2 & golongan & $\begin{array}{c}\text { Varch } \\
\text { ar }\end{array}$ & 18 & $\begin{array}{l}\text { Golongan/pan } \\
\text { gkat guru }\end{array}$ \\
\hline
\end{tabular}

\section{5) Tabel Gaji}

Tabel gaji digunakan untuk menampung data-data guru sertifikasi berdasarkan golongan. Adapun rancangan tabelnya dapat dilihat pada tabel 5 berikut :

\section{Tabel 5 Tabel Gaji}

\begin{tabular}{|c|c|c|c|c|}
\hline \multicolumn{2}{|c|}{$\begin{array}{l}\text { Nama Tabel } \\
\text { Index } \\
\text { KEY) }\end{array}$} & \multicolumn{3}{|c|}{$\begin{array}{l}\text { tb_gaji } \\
\text { id_gaji, id_golongan ( FOREIGN }\end{array}$} \\
\hline $\begin{array}{l}\mathbf{N} \\
\mathbf{0}\end{array}$ & $\begin{array}{l}\text { Nama } \\
\text { Field }\end{array}$ & $\begin{array}{l}\text { Type } \\
\text { Field }\end{array}$ & $\begin{array}{c}\text { Panjan } \\
\mathrm{g}\end{array}$ & $\begin{array}{l}\text { Keteranga } \\
\mathbf{n}\end{array}$ \\
\hline 1 & Id_gaji & Int & 5 & Id gaji \\
\hline 2 & $\begin{array}{l}\text { Id_golonga } \\
\mathrm{n}\end{array}$ & Int & 5 & Id golongan \\
\hline 3 & gaji & $\begin{array}{c}\text { Numbe } \\
\text { r }\end{array}$ & 20 & $\begin{array}{l}\text { Gaji } \\
\text { berdasarkan } \\
\text { golongan }\end{array}$ \\
\hline
\end{tabular}

6) Tabel Berkas
Tabel berkas digunakan untuk menyimpan data berkas pelaporan guru sertifikasi. Adapun rancangan tabelnya dapat dilihat pada tabel 6 berikut :

\section{Tabel 6 Berkas}

\begin{tabular}{|c|c|c|c|c|}
\hline \multicolumn{2}{|c|}{$\begin{array}{l}\text { Nama Tabel } \\
\text { Index }\end{array}$} & \multicolumn{3}{|c|}{$\begin{array}{l}\text { : berkas } \\
\text { : id_berkas } \\
\text { Nuptk (foreign key) }\end{array}$} \\
\hline $\begin{array}{l}\mathbf{N} \\
\mathbf{0}\end{array}$ & Nama Field & $\begin{array}{l}\text { Type } \\
\text { Field }\end{array}$ & $\begin{array}{c}\text { Panja } \\
\text { ng }\end{array}$ & $\begin{array}{c}\text { Keterang } \\
\text { an }\end{array}$ \\
\hline 1 & id_berkas & Int & 10 & $\begin{array}{l}\text { Id kode } \\
\text { berkas }\end{array}$ \\
\hline 2 & nuptk & $\begin{array}{c}\text { Varch } \\
\text { ar }\end{array}$ & 16 & $\begin{array}{l}\text { Nuptk } \\
\text { guru }\end{array}$ \\
\hline 3 & Sk_berkala & $\begin{array}{c}\text { Varch } \\
\text { ar }\end{array}$ & 100 & $\begin{array}{l}\text { Scan sk } \\
\text { berkala }\end{array}$ \\
\hline 4 & $\begin{array}{l}\text { Sk_pembagian_t } \\
\text { ugas }\end{array}$ & $\begin{array}{l}\text { Varch } \\
\text { ar }\end{array}$ & 100 & $\begin{array}{l}\text { Scan sk } \\
\text { pembagia } \\
n \text { tugas }\end{array}$ \\
\hline
\end{tabular}

\section{7) Tabel Rekap Tunjangan}

Tabel rekap tunjangan digunakan untuk menyimpan data hasil rekap tunjangan yang akan dibayarkan. Rancangannya dapat pada tabel 7 berikut :

\section{Tabel 7 Tabel Rekap Tunjangan}

\begin{tabular}{|c|c|c|c|c|}
\hline \multicolumn{2}{|c|}{$\begin{array}{l}\text { Nama Tabel } \\
\text { Index }\end{array}$} & \multicolumn{3}{|c|}{$\begin{array}{l}\text { : tbrekaptunjangan } \\
: \text { no peserta (PRIMARY KEY) }\end{array}$} \\
\hline $\begin{array}{l}\mathbf{N} \\
\mathbf{0}\end{array}$ & Nama Field & $\begin{array}{l}\text { Type } \\
\text { Field }\end{array}$ & $\begin{array}{c}\text { Panjan } \\
\mathrm{g}\end{array}$ & $\begin{array}{c}\text { Keteranga } \\
\mathbf{n}\end{array}$ \\
\hline 1 & No_peserta & $\begin{array}{c}\text { Varcha } \\
\text { r }\end{array}$ & 16 & $\begin{array}{l}\text { Nomor } \\
\text { nuptk }\end{array}$ \\
\hline 2 & nama & $\begin{array}{c}\text { Varcha } \\
\text { r }\end{array}$ & 25 & Nama guru \\
\hline 3 & nip & $\begin{array}{c}\text { Varcha } \\
\text { r }\end{array}$ & 18 & Nip guru \\
\hline 4 & golongan & Varcha & 10 & Golongan \\
\hline
\end{tabular}




\begin{tabular}{|l|l|c|c|l|}
\hline 5 & $\begin{array}{l}\text { Tempat } \\
\text { tugas }\end{array}$ & $\begin{array}{c}\text { Varcha } \\
\mathrm{r}\end{array}$ & 30 & $\begin{array}{l}\text { Sekolah } \\
\text { tempat } \\
\text { tugas }\end{array}$ \\
\hline 6 & Masa_kerja & INT & 4 & Lama kerja \\
\hline 7 & Id_gapok & INT & 5 & Gaji Pokok \\
\hline 8 & $\begin{array}{l}\text { Jml_tunjanga } \\
\mathrm{n}\end{array}$ & $\begin{array}{c}\text { Numbe } \\
\mathrm{r}\end{array}$ & 20 & $\begin{array}{l}\text { Jumlah } \\
\text { tunjangan }\end{array}$ \\
\hline 9 & Pph21 & $\begin{array}{c}\text { Numbe } \\
\mathrm{r}\end{array}$ & 30 & $\begin{array}{l}\text { Potongan } \\
\text { Pph21 }\end{array}$ \\
\hline 10 & Jml_diterima & $\begin{array}{c}\text { Numbe } \\
\mathrm{r}\end{array}$ & 20 & $\begin{array}{l}\text { Total } \\
\text { Diterima }\end{array}$ \\
\hline 11 & npwp & Int & 30 & \\
\hline 12 & No_rekening & Int & 30 & \\
\hline 13 & Nama_bank & $\begin{array}{c}\text { Varcha } \\
\mathrm{r}\end{array}$ & 20 & \\
\hline 14 & AnRekBank & $\begin{array}{c}\text { Varcha } \\
\mathrm{r}\end{array}$ & 30 & \\
\hline
\end{tabular}

\section{HASILDAN PEMBAHASAN}

\subsection{Halaman Utama}

Rancangan halaman utama sistem memiliki beberapa konten yang diantaranya home, profil, gaji, tentang kami, status verifikasi, sekolah, guru, golongan dan ada juga form login yang dapat digunakan guru dan admin untuk masuk ke dalam sistem.. Adapun tampilan halaman utama adalah sebagai berikut :

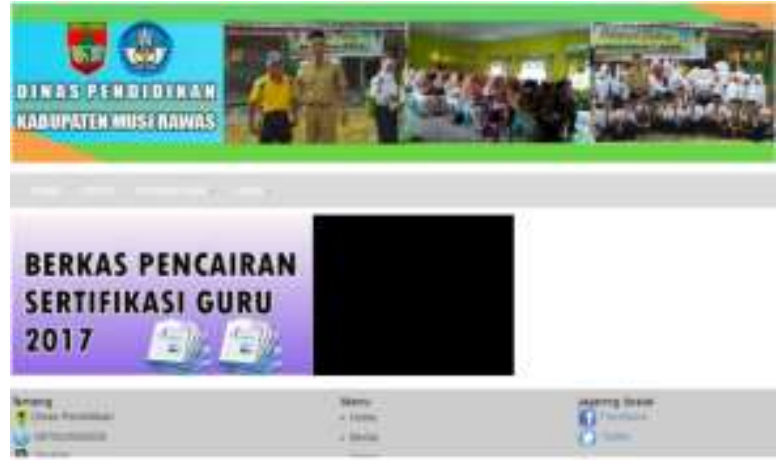

\section{Gambar 4 Halaman Utama}

\subsection{Halaman Login}

Rancangan halaman login admin ini berisikan username dan password. Halaman login salah syarat untuk masuk kedalam sistem ini, yang bisa login hanya yang mempunyai hak akses yaitu admin dan guru. Adapun tampilan halaman login adalah sebagai berikut :

\section{Login Administrator}

\section{Username}

Password

\section{$\log$ in}

\section{Gambar 3.2 Halaman Login}

\subsection{Halaman Data Guru}

Halaman ini digunakan untuk menampilkan input data guru merupakan halaman kendali yang 
dipegang oleh admin. Dimana fungsinya adalah untuk menginput data guru pada aplikasi sistem sertifikasi berbasis web Adapun tampilan dari input data guru adalah sebagai berikut :

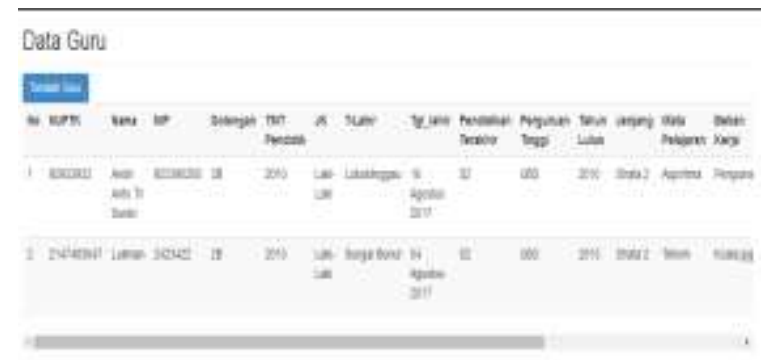

\section{Gambar 3.3 Halaman Input data guru}

\subsection{Halaman Input Sekolah}

Halaman ini digunakan untuk melakukan tambah sekolah. Adapun tampilan dari halaman input sekolah adalah sebagai berikut :

\section{Gambar 3.4 Halaman Input Sekolah}

\subsection{Halaman Verifikasi Data Guru}

Halaman ini digunakan untuk menampilkan data guru yang belum diverifikasi. Adapun tampilan dari halaman verifikasi data guru adalah sebagai berikut :

\section{Dala Guru Yang Beum Ci Verikas}

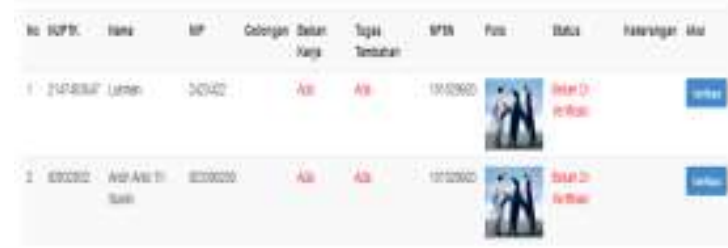

\section{Gambar 3.5 Halaman Verifikasi}

\subsection{Halaman Upload Berkas}

Halaman ini digunakan untuk mengupload berkas sertifikasi. Adapun tampilan dari halaman upload berkas adalah sebagai berikut :

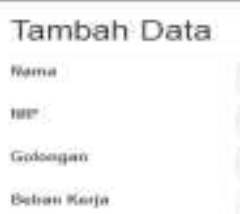

Gambar 3.7 Halaman Upload Berkas 3.7 Halaman Lihat Rekap Per Periode Halaman ini digunakan untuk melihat laporan rekap per periode. Adapun tampilan dari halaman rekap pembayaran adalah sebagai berikut : 


\section{Buat Rekap}

Periode

\section{Lhat}

\section{Gambar 3.8 Halaman Lihat Rekap Per}

Periode

\subsection{Halaman Laporan Rekap}

\section{Pembayaran}

Halaman ini mencetak rekap

laporan pembayaran sertifikasi guru.

Adapun tampilan dari halaman laporan

rekap pembayaran adalah sebagai berikut

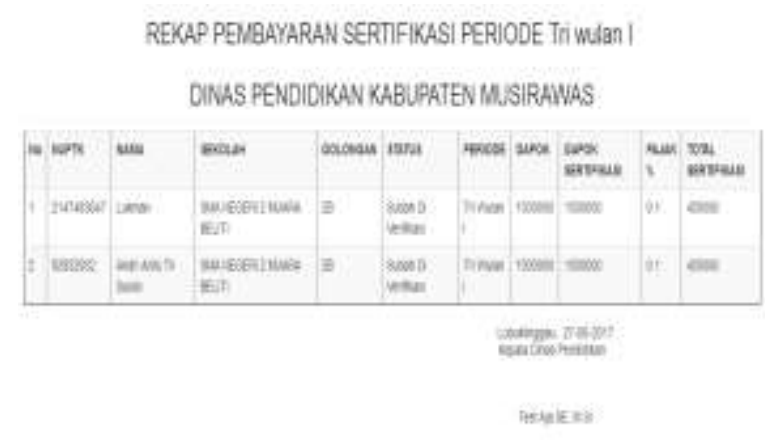

\section{Gambar 3.9 Halaman Laporan Rekap}

Pembayaran

\section{SIMPULAN}

Berdasarkan dari uraian diatas maka penulis dapat menyimpulkan.

1. Membantu dinas pendidikan dalam memverifikasi berkas pelaporan data guru sertifikasi sehingga mempermudah dalam pembuatan laporan.

2. Mempermudah guru memantau dan melaporkan berkas beban kerja kepada dinas pendidikan.

3. Mempercepat proses pencairan dana sertifikasi guru karena berkas pelaporan bisa proses secara online

\section{DAFTAR RUJUKAN}

Agus Saputra (2011). Trik dan Solusi Jitu Pemrograman PHP. IKAPI., Jakarta.

Husni Iskandar Pohan \& Kusnassriyanto Saiful Bahri, 1997, "Pengantar Perancangan Sistem", Erlangga, Jakarta.

Mukti, Y. (2018). Sistem Informasi Madrasah Aliyah Negeri Pagar Alam Berbasis Web. Indonesian Journal of Computer Science, 6(2), 192-205. https://doi.org/10.33022/ijcs.v6i2.42

Sukarso. 2005. Pengertian dan Fungsi Laboratorium. Online http://wanmustafa.wordpress.com/20 11/06/12/pengertian-danfungsilaboratorium/, diakses pada tanggal 03 November 2019 pukul 14.24.

Oetomo Budi Sutedjo Dharma. 2002. Perencanaan dan Pengembangan Sistem Informasi. Edisi I. ANDI Yogyakarta

Sutabri, Tata, Analisa Sistem Informasi, ANDI, Yogyakarta, 2005

Whitten, Jeffrey L, et al, Metode Desain \& Analisis Sistem, Edisi 6, Edisi International, Mc GrawHill, ANDI, Yogyakarta: 2004. 